\title{
Spontaneous pneumomediastinum complicating asthma exacerbation
}

\author{
Chukwudumebi Okafor, Sarthak Soin, ${ }^{\ominus}$ Joao Francisco Figueiredo Marcondes Ferraz
}

Department of Internal

Medicine, Presence Saint Joseph Hospital, Chicago, Illinois, USA

Correspondence to Dr Sarthak Soin, sarthaksoin@gmail.com

Accepted 22 January 2019

\section{DESCRIPTION}

Pneumomediastinum is an uncommon condition characterised by the accumulation of air in the mediastinum. Pneumomediastinum is frequently associated with other forms of extra-alveolar air, including pulmonary interstitial emphysema, pneumopericardium, pneumothorax, subcutaneous emphysema, pneumoretroperitoneum and pneumoperitoneum. ${ }^{1}$ The majority of patients with spontaneous pneumomediastinum have predisposing factors that cause increase in airway pressure, which leads to alveolar rupture. Most commonly, this results from straining against a closed glottis (Valsalva manoeuvre) as during vomiting, coughing, or exercising. ${ }^{2}$ Oesophageal perforation (OE) is another important cause of spontaneous pneumomediastinum. However, these individuals are more likely to present with history of multiple or severe episodes of emesis and retching along with features of shock such as hypotension and tachycardia. ${ }^{3} \mathrm{OE}$ are often complicated by mediastinitis and sepsis, early diagnostic imaging is the goal in order to improve survival. ${ }^{45}$ The incidence of pneumomediastinum in adult patients with asthma exacerbations is unknown. ${ }^{67}$ Vianello et al published a study of 45 patients with severe acute asthma exacerbations who underwent radiologic imaging on admission and found that $11 \%$ had pneumomediastinum. ${ }^{8}$

A 22-year-old man with asthma who presented to the emergency department with complaints of breathlessness, pleuritic chest pain that was non-radiating and cough associated with post-tussive emesis for 1 day. He had no history of intubations and was not on maintenance asthma therapy. On admission, his vitals were blood pressure $122 / 58 \mathrm{~mm} \mathrm{Hg}$, heart rate $160 / \mathrm{min}$ and respiratory rate $40 / \mathrm{min}$, saturating $87 \%$ on room air and

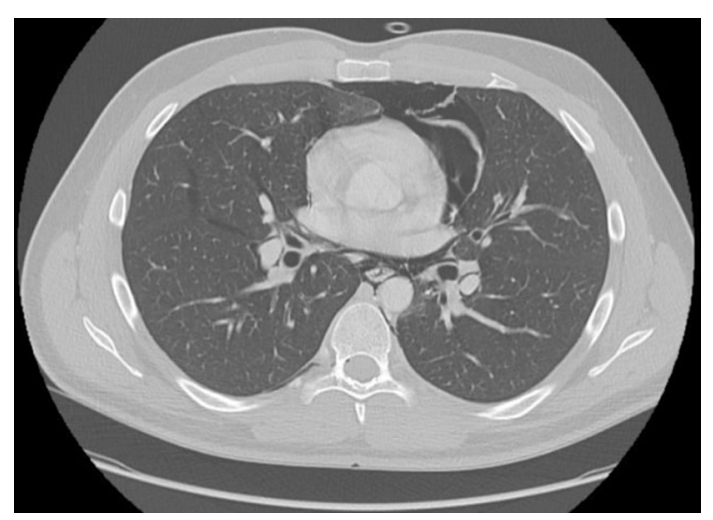

Figure 1 CT chest axial showing large pneumomediastinum in the pericardial region.

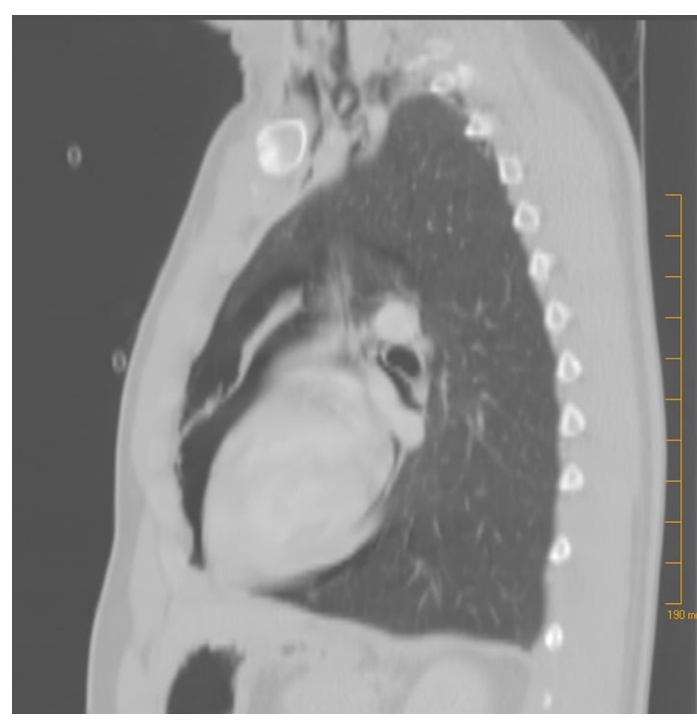

Figure $2 \mathrm{CT}$ chest sagittal showing prominent pneumomediastinum extending throughout the middle mediastinum and superior mediastinum well into the soft tissues of the neck.

temperature $37^{\circ} \mathrm{C}$. Physical examination was significant for respiratory distress with use of his accessory muscles for respiration, widespread rhonchi bilaterally and prolonged expiratory phase but no stridor. On palpation subcutaneous emphysema extended from the anterior neck down to the infraclavicular regions into his bilateral axilla.

Blood work-up showed elevated white cell count $20 \times 10^{9} / \mathrm{L}$, lactate $6.6 \mathrm{mmol} / \mathrm{L}$ and anion gap of $13 \mathrm{mEq} / \mathrm{L}$. Blood cultures and influenza/respiratory syncytial virus (RSV) PCR were unremarkable. Chest X-ray showed linear lucencies traversing the mediastinum and low neck consistent with pneumomediastinum. CT chest showed a very large pneumomediastinum throughout the chest extending well into the neck (figures 1 and 2). There was

\section{Learning points}

- Spontaneous mediastinum occurs as a result of sudden rise in the intra-alveolar pressure resulting in rupture of alveoli.

- Management is conservative, however high flow oxygen might enhance the reabsorption of air from the mediastinum.

- CT chest imaging is an important initial diagnostic tool if spontaneous pneumomediastinum secondary to oesophageal perforation is suspected. 
air surrounding the oesophagus although no focal oesophageal abnormality was noted effectively ruling out OE in absence of features of shock. There was prominent pneumopericardium and air extending into the spinal canal at the level of the thoracic and cervical spine. Repeat chest X-rays showed persistent subcutaneous emphysema with pneumomediastinum but no evidence of pneumothorax.

He was managed with high-flow oxygen, nebulised bronchodilators, intravenous steroids, fluids and morphine for pain and was subsequently discharged on day three of admission.

Acknowledgements Dr. William M. Sanders MD, Department of Pulmonology at Presence Saint Joseph Hospital Chicago

Contributors CO, SS and JFFMF have contributed equally in writing and reviewing of the manuscript. SS is the article guarantor.

Funding The authors have not declared a specific grant for this research from any funding agency in the public, commercial or not-for-profit sectors.

Competing interests None declared.

Patient consent for publication Not required.
Provenance and peer review Not commissioned; externally peer reviewed.

\section{REFERENCES}

1 Cameron DW. Nonneoplastic disorders of the mediastinum. Fishman's pulmonary diseases and disorders. Fifth Edition. New York, NY: McGraw-Hill, 2015.

2 Meireles J, Neves S, Castro A, et al. Spontaneous pneumomediastinum revisited. Respir Med CME 2011:4:181-3.

3 Akinyemi R, Ogah O, Akisanya C, et al. Pneumomediastinum and subcutaneous emphysema complicating acute exacerbation of bronchial asthma. Ann Ib Postgrad Med 2007:5:78-9.

4 Brinster CJ, Singhal S, Lee L, et al. Evolving options in the management of esophageal perforation. Ann Thorac Surg 2004;77:1475-83.

5 Koullias GJ, Korkolis DP, Wang XJ, et al. Current assessment and management of spontaneous pneumomediastinum: experience in 24 adult patients. Eur I Cardiothorac Surg 2004;25:852-5

6 Potz BA, Chao LH, Ng TT, et al. Clinical significance of spontaneous pneumomediastinum. Ann Thorac Surg 2017;104:431-5.

7 Faruqi S, Varma R, Greenstone MA, et al. Spontaneous pneumomediastinum: a rare complication of bronchial asthma. J Asthma 2009;46:969-71.

8 Vianello A, Caminati M, Chieco-Bianchi F, et al. Spontaneous pneumomediastinum complicating severe acute asthma exacerbation in adult patients. J Asthma 2017:9:1-7.

Copyright 2019 BMJ Publishing Group. All rights reserved. For permission to reuse any of this content visit https://www.bmj.com/company/products-services/rights-and-licensing/permissions/

BMJ Case Report Fellows may re-use this article for personal use and teaching without any further permission.

Become a Fellow of BMJ Case Reports today and you can:

- Submit as many cases as you like

Enjoy fast sympathetic peer review and rapid publication of accepted articles

- Access all the published articles

- Re-use any of the published material for personal use and teaching without further permission

For information on Institutional Fellowships contact consortiasales@bmjgroup.com

Visit casereports.bmj.com for more articles like this and to become a Fellow 